\title{
TROSKI OJCA \\ WYSYŁAJĄCEGO SYNÓW PO EDUKACJĘ ZA GRANICĘ W ŚWIETLE KORESPONDENCJI STANISŁAWA M. RZEWUSKIEGO WOJEWODY PODLASKIEGO Z LAT 1720-1727
}

Słowa kluczowe: podróż edukacyjna, guwerner, Seweryn Rzewuski, Stanisław Mateusz Rzewuski, Marcin Kawiecki

Jednym z elementów kształcenia młodego szlachcica w okresie nowożytnym były zagraniczne podróże edukacyjne, które mają już pokaźną literaturę ${ }^{1}$. Cel tego krótkiego artykułu jest ograniczony do przedstawienia podróży edukacyjnych z punktu widzenia ojca Stanisława Mateusza Rzewuskiego, wojewody podlaskiego, hetmana polnego koronnego (później wojewody bełskiego i hetmana wielkiego koronnego) ${ }^{2}$, który dbał o edukację swoich synów, Seweryna Józefa (starszego) ${ }^{3}$ i Wacława (młodszego) ${ }^{4}$. Podstawę źródłową artykułu stanowi korespondencja hetmana z synami oraz z ich guwernerem Marcinem Kawieckim ${ }^{5}$.

1 Wystarczy tutaj przytoczyć ostatnie publikacje: D. Ż ołą d ź, Ideały edukacyjne doby staropolskiej. Stanowe modele i potrzeby edukacyjne szesnastego i siedemnastego wieku, Warszawa-Poznań 1990; I. Zatorska, M. Ka me cka (éd.), Les Polonais en France 1696-1795. Bio-bibliographie provisoire, Łask, 2010; A. Marki ewicz, Podróże edukacyjne w czasach Jana III Sobieskiego. Peregrinationes Jablonovianae, Warszawa 2011; M. K a m e c k a , ,Do cudzych krajów”. Edukacyjne podróże szlachty polskiej do Francji w epoce saskiej, Białystok 2012; Polski Grand Tour w XVII i poczatkach XIX w., A. R oć k o (red.), Warszawa 2014.

2 A. Link-Lenczowski, Rzewuski Stanisław Mateusz h. Krzywda (1662-1728), hetman polny, później wielki koronny, wojewoda betski, w: Polski Stownik Biograficzny (dalej: PSB), t. 34, 1992, s. $152-158$.

3 Seweryn Józef zmarł w 1754 r. Aktywny politycznie, działał w konfederacji dzikowskiej, kilkakrotny poseł na sejm za panowania Wettinów, starosta chełmski, lubomelski, referendarz wielki koronny 1738-1750, wojewoda wołyński 1750-1754, podczaszy wielki koronny 1726-1738.

4 Z. Zi eliń s ka, Rzewuski Wactaw (dalsze imiona: Piotr, Rafat, Onufry, Ignacy i z bierzmowania Józef) h. Krzywda (1706-1779), hetman polny, a następnie hetman w. kor., kasztelan krakowski, wojewoda betski, w: PSB, t. 34, 1992, s. 169-180.

5 Z zachowanych obszernych zbiorów korespondencji hetmana S.M. Rzewuskiego najwięcej listów do synów przechowywanych jest w: Bibliotece Czartoryskich (dalej: BCz), rkps 561 IV, 
Sam hetman po zakończeniu nauki w szkole jezuitów we Lwowie odbył zagraniczną podróż edukacyjną. Instrukcję podróżną otrzymał od ojca (nie zachowała się) i od hetmana Jabłonowskiego 1 IX 1682 r. ${ }^{6}$ Od końca 1682 r. towarzyszył w drodze z Częstochowy do Pragi młodym wojewodzicom ruskim Aleksandrowi Janowi i Janowi Stanisławowi Jabłonowskim, synom Stanisława Jana, wojewody ruskiego (1664-1692), hetmana wielkiego koronnego i kasztelana krakowskiego (1692-1702) 7 . Stamtąd na polecenie hetmana Jabłonowskiego 9 X 1682 r. wyjechał do Paryża, aby rok uczyć się w akademii Jeana Bernardego. Przez kolejny rok miał służyć w muszkieterach króla francuskiego, a trzeci rok spędzić w podróży: z Paryża przez Rzym, Loretto, Florencję, Wenecję i następnie, po dwu- lub trzymiesięcznym pobycie w Wiedniu, miał wracać do Polski ${ }^{8}$.

Niewiele mamy informacji w literaturze o kolejach losu starszego syna hetmana, Seweryna, przed wyjazdem za granicę. Pierwsze wzmianki o działalności publicznej pochodzą z 1717 r., gdy był rotmistrzem pancernym². 16 IX $1718 \mathrm{r}$. we Włodzimierzu na powtórnym sejmiku przedsejmowym został wybrany posłem województwa czernihowskiego na sejm w Grodnie ${ }^{10}$. Na sejmie z limity w Warszawie (30 XII 1719 - 22 II 1720) występował już jako starosta lubomski (lubomelski), a potem był na sejmiku relacyjnym ${ }^{11}$. W tym okresie występował też jako starosta chełmski ${ }^{12}$. W sierpniu 1720 r. uczestniczył w obradach sejmiku przedsejmowego chełmskiego i został jego marszałkiem oraz podpisał instrukcje

558 IV, 2171 IV oraz Bibliotece Jagiellońskiej (dalej: BJ), rkps 5624, 5269. Często są to kopie tych samych listów. Fragmenty korespondencji do synów znajdują się w BJ, BCz, Bibliotece Narodowej, Bibliotece Uniwersytetu Warszawskiego, Bibliotece Zakładu Ossolińskich we Wrocławiu i we Lwowie oraz w Bibliotece im. Zielińskich Towarzystwa Naukowego Płockiego.

${ }^{6}$ Informacja Stanisławowi Rzewuskiemu jadącemu do cudzych krajów (1682), oprac. Anna Markiewicz, w: Ojcowskie synom przestrogi. Instrukcje rodzicielskie (XVI-XVII w.), wstęp i objaśnienia D. Żołądź-Strzelczyk, M. E. Kowalczyk, Wrocław 2017, s. 491-502.

${ }^{7} \mathrm{O}$ ich podróży bogata literatura, m.in.: A. Markiewicz, Podróże edukacyjne w czasach Jana III Sobieskiego. Peregrinationes Jablonovianae, Warszawa 2011; Stanisław Jan J a bło n ow s k i, Instrukcja i addytament dla synów na peregrynację do cudzych krajów (1682), oprac. A. Markiewicz, w: Ojcowskie synom przestrogi. Instrukcje rodzicielskie (XVI-XVII w.), wstęp i objaśnienia D. Żołądź-Strzelczyk, M. E. Kowalczyk, Wrocław 2017, s. 463-489.

${ }^{8}$ Polecenia hetmana Jabłonowskiego w Informacji... oraz w instrukcji dla synów. Także J.M. Ko s s o w ic z, Diariusz podróży po Europie (1682-1688), oprac., wstęp i komentarz A. Markiewicz, Warszawa 2017.

${ }^{9}$ Mamy niewiele informacji biograficznych, m.in.: W. B ondyra, Reprezentacja sejmikowa Rusi Czerwonej w czasach saskich, Lublin 2005, s. 186.

${ }^{10}$ Archiv Jugozapadnoj Rosii (AJZR), Kijów 1861, t. II, cz. III, s. 597-599; BCz, rkps 5939, nr 36 088, list S. M Rzewuskiego do J. Szembeka, Nowosiółki 18 XI 1718.

${ }_{11}$ Teka Gabriela Junoszy Podoskiego, wyd. K. Jarochowski, Poznań 1854, t. II s. 82 Sejmik relacyjny 29 IV 1720; U. K o s iń s k a, Sejm 1719-1720 a sprawa traktatu wiedeńskiego, Warszawa 2003, s. 271.

${ }_{12}$ K. Chła pow s ki Starostowie niegrodowi w Koronie 1565-1795. Materiaty źródłowe, Warszawa 2017, s. 222; jego ojciec S.M. Rzewuski posiadał starostwo lubomelskie od $1710 \mathrm{r}$. 
sejmiku ${ }^{13}$. Dopiero po sejmiku zapadły ostateczne decyzje w sprawie wyjazdu za granicę.

Jego ojciec przygotowywał wyprawę przynajmniej od początku 1720 r. Rozpoczął od poszukiwania odpowiedniego opiekuna. Zbierał rekomendacje od różnych osób, m.in. Janusza A. Wiśniowieckiego, wojewody krakowskiego, i Jana S. Szembeka, kanclerza wielkiego koronnego. W marcu 1720 r. miał już kilku kandydatów do tej funkcji, którzy byli doświadczeni i kompetentni - co dobrze świadczy o poszukiwaniach hetmana - a wśród nich znaleźli się: Marcin Kawiecki, którego rekomendował Wiśniowiecki, Krzysztof Gaspary, sekretarz królewski, oraz Kazimierz Młocki, także sekretarz królewski, którego rekomendował kanclerz ${ }^{14}$.

Kazimierz Młocki był doświadczonym opiekunem młodzieży, gdyż w latach 1712-1719 był perceptorem synów Stanisława Antoniego Szczuki, podkanclerzego litewskiego, i Konstancji Marii z Potockich - Marcina Leopolda, późniejszego starosty wąwolnickiego, i Jana Kantego, późniejszego starosty wiekszniańskie$\mathrm{go}^{15}$. Pracował dla kanclerza Szembeka, potem został sekretarzem pieczęci mniejszej u podkanclerzego Jan Lipskiego, a następnie w czasie panowania Augusta III był sekretarzem pieczęci większej.

Krzysztof Gaspary początkowo był związany z Jakubem Flemmingiem i przynajmniej od 1712 r. pracował w Dreźnie ${ }^{16}$. Około 1713 r. opuścił jego służbę i wrócił do kraju. Wówczas chyba podjął się funkcji opiekuna starosty kamienieckiego w podróży do Francji ${ }^{17}$. Był to prawdopodobnie Jan Stanisław Kątski, późniejszy generał artylerii ${ }^{18}$. Po powrocie w $1716 \mathrm{r}$. negocjował propozycję objęcia posady guwernera Jana Jerzego, syna Urszuli K. Bokum, księżnej cieszyńskiej. Byli w trakcie rozmów z królem o uzyskanie zgody na wyjazd, gdy Gaspary otrzymał propozycję pracy w gabinecie saskim. Obawiał się jednak przyjęcia takiej pracy. Twierdził, że od czasu opuszczenia służby u Flemminga w swoich podróżach miał zbyt mało okazji do posługiwania się językiem niemieckim

13 W. B ondyra, Chronologia sejmików ziemi chetmskiej 1697-1762, „Rocznik Chełmski”, t. II, s. 358, 363; BCz, rkps 558 IV, s. 276-280: informacja w liście z Chełma 12 IX 1720.

${ }^{14} \mathrm{BCz}$, rkps 558 IV, s. 129-131: S.M. Rzewuski hetman polny kor. do J.A. Wiśniowieckiego wojewody krakowskiego, Luboml 6 III 1720.

${ }^{15}$ U. Kicińska, Listy Kazimierza Młockiego, preceptora młodych Szczuków, jako przykład źródła do badań nad staropolskimi podróżami edukacyjnymi, w: Źródła do dziejów staropolskich podróżny edukacyjnych, pod red. D. Żoładź-Strzelczyk i M.E. Kowalczyk, Wrocław 2017, s. 327-344.

${ }^{16}$ Sächsiches Staatsarchiv, Hapuptstaatsarchiv Dresden (dalej: SHStA), 10026 Geheimes Kabinett, Loc.00687/05 Des Generalfeldmarschalls Herrn Graf von Flemming Korrespondenz mit: ...Gaspari, Sekretär, 1712-1728, k. 63 Gaspari, Drezno 15 VII 1712.

17 BCz, rkps 2190, s. 133-136: list do Wawrzyńca Sardiego generała poczt z Paryża 16 III 1714 oraz s. 137-140: jw. list z Bordeaux 24 VII 1714.

${ }_{18}$ E. Rabowi c z, P. S tok, Kątski Jan Stanisław h. Brochwicz (ok. 1685-1727) generał ziem podolskich, gen. artylerii, miecznik kor., literat, w: PSB, t. 12, s. 314-315. 
i łaciną ${ }^{19}$. Nie znamy dokładnie dalszych jego losów, ale pozostawał w kręgu dworu i poszukiwał pracy. Wiemy, że zabiegał o urząd pocztmistrza litewskiego, jednak po jego otrzymaniu napotkał trudności w objęciu tego urzędu ${ }^{20}$. Początkowo był głównym kandydatem na guwernera dla syna Rzewuskiego ${ }^{21}$, dlatego hetman czekał cierpliwie na jego powrót, ale w końcu zdecydował się na Kawieckiego $^{22}$. Gaspary jednak nie utrzymał się na pocztmistrzostwie litewskim. Nie miał już ochoty kontynuować pracy guwernera i być w ciągłych podróżach. Wyjechał do matki do Gdańska, chroniąc się przed kolejnymi propozycjami, skąd prosił Flemminga o znalezienie jakiegoś stanowiska ${ }^{23}$. Potem przeszedł do służby w kancelariach królewskich.

Ostatecznie hetman przyjął usługi Kawieckiego, twierdząc, że „nie może być nikt zdolniejszy" do opieki nad jego synem. Prosił, aby Wiśniowiecki zatrzymał go do swego powrotu na Wołyń do Błudowa. Rozmowy z nim zamierzał zakończyć w Targowicy ${ }^{24}$. Kawiecki pochodził z Wielkopolski. Jego kariera toczyła się w środowisku wojskowym. Przed zaangażowaniem się u Rzewuskich przebywał w Paryżu. Możliwe, że już w latach 1705-1708 był guwernerem Antoniego K. Sapiehy, starosty mereckiego ${ }^{25}$. Ponownie był w Paryżu w $1718 \mathrm{r}$. Na pewno stał się odtąd jednym z niemal zawodowych guwernerów, podejmujących się opieki nad młodzieżą szlachecką i magnacką odbywającą zagraniczne podróże edukacyjne ${ }^{26}$.

19 SHStA, 10026 Geheimes Kabinett, Loc.00687/05 Des Generalfeldmarschalls Herrn Graf von Flemming Korrespondenz mit: ...Gaspari, Sekretär, 1712-1728, k. 66-67 list K. Gasparego z 8 IV 1716.

${ }^{20} \mathrm{BCz}$, rkps 558 IV, s. 129-131: S.M. Rzewuski do J. Wiśniowieckiego wojewody krak., Luboml 6 III 1720.

${ }^{21}$ Ibidem oraz Biblioteka Kórnicka (dalej: B. Kórn.), rkps 423, k. 125v: drugi list Rzewuskiego, Luboml 25 IV 1720.

${ }^{22}$ B. Kórn., rkps 423, k. 127-127v: S.M. Rzewuski hetman polny kor. do J. Wiśniowieckiego wojewody krak., Luboml 11 IV 1720.

${ }^{23}$ SHStA, 10026 Geheimes Kabinett, Loc. 00687/05 Des Generalfeldmarschalls Herrn Graf von Flemming Korrespondenz mit: ... Gaspari, Sekretär, 1712-1728, k. 68: list K. Gasparego, Heilsberg 26 XII 1720.

${ }^{24}$ B. Kórn., rkps 423, k. 127-127v: S.M. Rzewuski hetman polny kor. do J. Wiśniowieckiego wojewody krak., Luboml 11 IV 1720; idem w BCz, rkps 558 IV, s. 133; Biblioteka im. Zielińskiego, Płock, rkps 56, k. 124-125: S.M. Rzewuski do J. Wiśniowieckiego woj. krak, Targowica 15 V 1720 oraz k. 126-127: jw., Targowica 22 V 1722.

${ }^{25}$ Lwowska Naukowa Biblioteka im. W. Stefanyka Akademii Nauk Ukrainy (dalej: LNBU), rkps 1311 I, k.179v: Unkoszta paryskie JMc pana starosty merckiego (21 050 tynfów) oraz s. 179: Reglement, które się obserwuje w akademiach paryskich z ordynacyi królewskiej ile pamiętać mogę (3179 franków), które znalazły się przy dokumentach przygotowywanych na rzecz podróży Seweryna Rzewuskiego.

${ }^{26}$ Jego sylwetka w: Marcin Ka w i e c k i, Refleksje do przyszłej peregrynacji Jmć Pana starosty chełmskiego (ok.1720), oprac. A. Markiewicz, w: Przestrogi i nauki dla dzieci. Instrukcje rodzicielskie (XVIII w.),wstęp i objaśnieniami opatrzyły M. E. Kowalczyk i D. Żołądź-Strzelczyk, Wrocław 2017, s. 19-21. 
Ojciec przygotował dla Kawieckiego krótką instrukcję przed podróżą. Hetman polecał jak najszybszy wyjazd, narzekając na syna, że dotąd marnotrawi czas. Radził synowi najpierw wyjazd do Paryża, gdzie miał nauczyć się różnych umiejętności i zapoznać z obyczajami dworu francuskiego. Seweryn powinien się uczyć języka francuskiego (który znał słabo) oraz włoskiego (nie znał wcale), aby mógł później lepiej zapoznać się z dworami włoskimi. Podróż miał zakończyć na dworze cesarskim w Wiedniu. Hetman nie chciał, aby Seweryn rozpoczął podróż od Włoch, gdyż obawiał się, że jego skłonność do lenistwa uniemożliwi mu nie tylko dobre poznanie kraju, ale także kształcenie się. Radził Kawieckiemu, aby na początku podróży miał odpowiednią władzę „nad Panieńciem”. Hetman nie określał wysokości koniecznych pensji, twierdząc, że często zmieniają się ceny i koszty utrzymania. Podkreślał jednak, że chcąc pozyskać jak najlepszych nauczycieli dla syna, będzie gotów „podwyższyć ordynaryjnej ekspensy”27.

Ostateczny kontrakt podpisano w Łukówku zapewne we wrześniu $1720 \mathrm{r}^{28}$ Ustalono, że podróż będzie trwała dwa lata, a hetman przeznaczy na nią $30000 \mathrm{zł}$ rocznie ${ }^{29}$. Roczny pobyt w Paryżu miał kosztować 24000 tynfów. Na utrzymanie Seweryna w Paryżu na pół roku hetman przeznaczył 1086 tynfów. Osobne sumy przeznaczył dla guwernera pokojowego i dwóch lokajów, wpis do Akademii, pensje dla różnych nauczycieli: nauczycieli od broni, mistrza walki, mistrza tańca, matematyka, historyka, geografa. Utrzymanie karety miało kosztować 1800 tynfów. Osobne wydatki roczne przewidziano na ubiory, pomoc do nauki, koszty pocztowe (125) itp. Wydatki na podróż i ewentualne dopłaty do wyżej wyliczonych kosztów miały zamknąć się w sumie 6000 tynfów ${ }^{30}$. Pierwszą ratę roczną otrzymał Kawiecki po podpisaniu kontraktu, jeszcze w Łukówku. Rzewuski spodziewał się, że suma ta powinna wystarczyć na pokrycie kosztów pobytu w Paryżu oraz kosztów podróży i pobytu w Rzymie ${ }^{31}$.

Po tych ustaleniach Seweryn i guwerner wyjechali do Warszawy, gdzie znaleźli się w początku października 1720 r. Zostali przyjęci przez J. Szembeka, kanclerza wielkiego koronnego na obiedzie. Przy stole kanclerz dał „kilka bardzo dobrych rad”, sugerując Sewerynowi, aby „strzegł się bywać w kompaniach młodych i takich, gdzie honor, zdrowie i dusza szwankować może". Pokazywał nawet przykłady jakichś królewiczów, którzy początkowo byli dobrze przyjęci przez dwór

${ }^{27}$ Ibidem, s. 19-27: Refleksyje starosty chetmskiego a s.p. Jmć. P[ana] wo[jewod]dy wotyński[ego] podane JW. Jmć Panu h[etmanowi] $w$ [ielkiemu] $k$ [oronnemu] ojcu jego przez Jmć P[ana] Kawieckiego guwernera tegoż; LNBU, rkps 1311 I, k.172-172v.

${ }^{28}$ BJ, rkps 5269, k. 81v-83: list do Kawieckiego, Targowica 8 IV 1722. Potem w korespondencji najczęściej pojawiają się określenia „do Kawieckiego guwernera syna starszego” i do „Seweryna starosty chełmskiego syna starszego".

${ }^{29}$ Ibidem, k. 58-59v: list do Kawieckiego, Luboml 21 II 1722.

${ }^{30}$ LNBU, rkps 1311 I, k. 180: Expensa siła na rok może kosztować w Paryżu Jaśnie wiel. $J M$ Pan starosta chetmski a przeszty JmP wda wotyński.

${ }^{31}$ BJ, rkps 5269, k. 81v-83: list do Kawieckiego, Targowica 8 IV 1722. 
paryski, ale „dla letkości niektórych siła stracili estymacyi” przez nadużywanie gier i hazardu. „In summa: jako ojcowski przyjaciel ojcowskie też dał napomnienie". Kanclerz był przeciwny, aby Seweryn jechał do Włoch przez Paryż i miał wątpliwości wobec akademii paryskiej. Obiecał wydać odpowiedni paszport do Berlina. Następnego dnia Seweryn z Kawieckim mieli odbyć wizytę u króla, a kanclerz ostrzegał ich przed przyznaniem się, że najpierw jadą do Paryża ${ }^{32}$. W czasie rozmowy z Augustem II przyznali się jednak, że najpierw jadą do Paryża. Król nie był z tego zadowolony, przypominając, że radził hetmanowi rozpoczęcie podróży od Włoch. Podobnego zdania był feldmarszałek Flemming ${ }^{33}$. Także Flemming przyjął go na obiedzie, po którym Seweryn odebrał rekomendacje do Drezna (dwa listy), Berlina, Hanoweru (dworu angielskiego) i Paryża. Ponadto Stanisław Poniatowski dał rekomendację do kanclerza króla angielskiego, a Jean V. Besenval, poseł francuski, do Paryża. Seweryn otrzymał także „macierzyńskie napomnienie" od żony posła francuskiego ${ }^{34}$.

W Warszawie za radą posła francuskiego i Marianiego uzgodnili, że należy uniknąć ryzyka utraty pieniędzy i wziąć ze sobą czerwone złote do ostatniego miasta przed granicą francuską, na przykład do Brukseli. Tam dopiero mieli porozumieć się bankierem Barbierem, aby zdecydować, czy można zabrać gotówkę do Paryża ${ }^{35}$.

Hetman zaplanował dla syna całą podróż edukacyjną, ale w praktyce plany te ulegały znacznej modyfikacji. Nie wiemy, z czym miał zapoznać się Seweryn w drodze do Paryża, gdyż brakuje informacji z tego pierwszego etapu podróży ${ }^{36}$. Wiemy, że planowali wyjechać z Warszawy 4 października 1720 r., kierując się do Koniecpola, a potem do Laszek pod Częstochową, gdzie był królewicz Jakub Sobieski. Stąd mieli jechać do Wrocławia ${ }^{37}$. Następnie przez Niemcy pojechali do Brukseli. Po drodze w listopadzie zatrzymali się na pewno w Berlinie, a później prawdopodobnie spędzili święta Bożego Narodzenia w Amsterdamie ${ }^{38}$.

W Brukseli zjawili się w końcu $1720 \mathrm{r}$. lub w początku 1721. Tutaj doszło do tragicznego wydarzenia, które rzuciło się cieniem na dalszy etap podróży Seweryna. W nocy z 26 na 27 stycznia 1721 r. Seweryn wdał się w pojedynek z woźnicą

${ }^{32}$ LNBU, rkps 1311 I, k. 173-173v: list Kampealauscu [?] do S.M. Rzewuskiego, Warszawa 1 X 1720.

33 Ibidem, k. 174: drugi list Kampealauscu [?], Warszawa 3 X 1720.

${ }^{34}$ Ibidem oraz k. 174 v: list Seweryna do ojca, Warszawa [bd.].

${ }^{35}$ Ibidem, k.175-175v: list Kawieckiego do S.M. Rzewuskiego hetmana p. kor., Warszawa $3 \times 1720$.

${ }^{36}$ Zakład Narodowy im. Ossolińskich (dalej: ZNiO), rkps 5173 I, s. 391-392: list hetmana do Seweryna, Warszawa 27 IX 1720. Wiemy tylko, że hetman w liście do syna domagał się relacji z Wrocławia, Drezna, Berlina i Hanoweru.

${ }^{37}$ Ibidem, k. 174 drugi list Kampealauscu [?], Warszawa 3 X 1720.

${ }^{38} \mathrm{ZNiO}$, rkps 5173 I: listy hetmana do M. Kawieckiego, s. 411 Warszawa 5 XII 1720 i s. 462 Luboml 31 I 1721. 
Mathieu du Jardin, którego ciężko zranił szpadą. Seweryn został aresztowany i był pilnowany w swoim pokoju przez trzech strażników rady miasta, a potem dodatkowo przez czterech muszkieterów. Zwolniony został dopiero kilka dni później, gdy okazało się, że ranny zdrowieje. Seweryn musiał zapłacić kaucję 1000 ecûs na koszty przyszłego procesu i wystawić odpowiedni weksel. Pieniądze pożyczył poczmistrz Deudon ${ }^{39}$.

Seweryn trochę inaczej opisał samą sprzeczkę z 26 stycznia - od potyczki słownej aż do lekkiego zranienia szpadą. Stan rannego dokładnie sprawdzili wezwani strażnicy. Następnego dnia, gdy okazało się, że rana nie jest groźna, Seweryn udał się do poszkodowanego. $\mathrm{Z}$ nim i jego żoną zawarł ugodę, która kosztowała go 50 dukatów, potocznie zwanych pistolami, liczonych jako 10 florenów brabanckich, i pokrył wszelkie dodatkowe koszty. Następnie zażądał od Herkulesa Józefa Turinetti, markiza de Prié, zastępcy generalnego gubernatora w Niderlandach (generalnym gubernatorem był książę Eugeniusz Sabaudzki) zwolnienia z aresztu. Ten zażądał najpierw kaucji 1000 talarów na ręce prokuratora generalnego ${ }^{40}$.

August II zawiadomił hetmana o pojedynku i jednocześnie wstawił się za Sewerynem u księcia i innych osób. Od tego czasu rozpoczęła się walka o uniknięcie procesu i długotrwałe zabiegi hetmana o odzyskanie depozytu. Hetman pisał do kanclerza Jana Szembeka i feldmarszałka Jakuba H. Flemminga, którzy mieli pomóc w ostatecznym rozwiązaniu problemu i interweniować poprzez dwór wiedeński ${ }^{41}$. Król pozwolił na interwencję i polecił przygotować odpowiednie listy dla Flemminga, które przekazać miał Manteuffel ${ }^{42}$. Jeszcze 3 lutego 1721 r. de Prié miał zapewniać Flemminga, że złożenie depozytu jest tylko zwykłą formalnością. Seweryn jednak nie doczekał się zwrotu pieniędzy i wyjechał do Paryża. Tymczasem w maju 1721 r. niespodziewanie próbowano doprowadzić do procesu ${ }^{43}$. W początku lipca markiz de Prié przekazał wezwanie do stawienia się w Brukseli przed prokuratorem generalnym. W swej odpowiedzi Seweryn stwierdził, że te żądania są bezprawne, tym bardziej, że strona poszkodowana otrzymała zadośćuczynienie. Oskarżył markiza de Prié o chęć zagarnięcia sumy depozytowej ${ }^{44}$.

39 SHStA, 10026 Geheimes Kabinett, Loc. 00684/01, Des Gen. Feld-Marschall H. Gr. von Flemming mit dem Kronsecretario Dembowski gephlogene Correspondenz, k. 116-117: S. Tombelle konsyliarz i prokurator generalny, Bruksela 2 V 1721.

40 Ibidem, s. 118-119: protest Seweryna z 21 VIII 1721 pisany po łacinie.

${ }^{41}$ BCz, rkps 558, s. 377-378: list Rzewuskiego do M. Kawieckiego, Nowsiółki 17 X 1721.

${ }^{42}$ SHStA, 10026 Geheimes Kabinett, Loc. 00684/01, Des Gen. Feld-Marschall H. Gr. von Flemming mit dem Kronsecretario Dembowski gephlogene Correspondenz, k. 28: Antoni S. Dembowski do J. H. Flemminga, Drezno 19 II 1721. Dodatkowo przesyłał je także Dembowski.

${ }^{43}$ SHStA, 10026 Geheimes Kabinett, Loc. 00684/01, Des Gen. Feld-Marschall H. Gr. von Flemming mit dem Kronsecretario Dembowski gephlogene Correspondenz, k. 116-117: S. Tombelle konsyliarz i prokurator generalny, Bruksela 2 V 1721. Wezwanie do stawienia się w Brukseli. Opublikowane w Wersalu 3 VII 1721.

${ }^{44}$ Ibidem, s. 118-119: protest Seweryna z 21 VIII 1721 pisany po łacinie. 
Seweryn zapewniał ojca o swej niewinności i chęci do nauki ${ }^{45}$. Hetman jednak był bardzo rozgoryczony. Wyrzucał sobie, że zlekceważył niepożądane oznaki jego zachowania. Jeszcze w kraju widział, że syn nie reagował na upomnienia ojca. Uważał, że teraz swoim zachowaniem i pojedynkiem, którego powinien unikać, przyniósł mu wstyd w Polsce i w Europie. Pisał do syna, iż na swoje nieszczęście nie zawiódł się w swoim przypuszczeniu, że z takim trudem ułożona wyprawa do cudzych krajów przyniesie mu większe żale niż radości, większą hańbę niż chwałę. Krytykował Seweryna, że zepsuł wysiłek wychowawczy guwernera i plany ojca. Wzywał go do opamiętania się, dyscypliny i poprawy zachowania, które grozi jego życiu i honorowi. Tłumaczył synowi, że zaprzepaszcza swoje szanse, gdyż podczas podróży król i Rzeczpospolita mogłyby go były wykorzystać w swoich interesach na dworach obcych, a teraz to raczej będzie wątpliwe ${ }^{46}$.

Chroniąc syna, hetman jednak prosił Karla H. von Hoyma, ministra saskiego w Paryżu, aby nie dopuścił do procesu i pomógł odzyskać pieniądze. Dodawał, że ranny wyzdrowiał i pokryte zostały wszelkie koszty (w tym zapłacono $300 \mathrm{du}-$ katów chirurgom $)^{47}$. Uzyskał też podobną obietnicę od Flemminga i miał nadzieję, że dwór wiedeński powstrzyma markiza de Prié przed dalszą zwłokąa ${ }^{48}$ Stale wzywał syna, aby sam przyczynił się do zwrotu pieniędzy i pisał „w terminach uniżonych" do Flemminga i markiza de Prié ${ }^{49}$. Ganił, gdy ten nie wykonywał jego polecenia, a właściwie działał na swoją szkodę. Ostrzegał, że w ten sposób może zrazić sobie ludzi, którzy jeszcze w przyszłości mogą mu być potrzebni ${ }^{50}$. Od księcia Eugeniusza otrzymał w końcu obietnicę zwrotu tych pieniędzy - miały być przekazane do Wiednia, kiedy Seweryn kończył już swoją podróż ${ }^{51}$.

9 lutego 1720 r. podróżnicy przybyli do Paryża, a następnego dnia Seweryn zapisał się do akademii François Guérinière znajdującej się koło Pałacu Luksemburskiego i zamieszkał w tej akademii, gdzie koszty utrzymania były podobne jak w innych akademiach, ale ogólnie wyższe niż dawniej. Kawiecki uważał, że tutaj Seweryn będzie miał lepsze warunki do ćwiczenia się w mowie francuskiej i pozostałych naukach. Poza tym guwerner chciał go odseparować od Polaków uczących się w innej akademii. Seweryn miał też dodatkowych pięciu nauczycieli, czyli: mistrzów od fortyfikacji, tańca, fechtunku, nauki języka oraz

${ }^{45}$ LNBU, rkps 1311 I, k. 175v-176: list Seweryna do ojca, Paryż 20 II 1720.

${ }^{46}$ BCz, rkps 2171 IV, s. 95-97: list hetmana do syna, 30 VI 1721.

${ }^{47}$ SHStA, 10026 Geheimes Kabinett, Loc. 00684/01, Des Gen. Feld-Marschall H. Gr. von Flemming mit dem Kronsecretario Dembowski gephlogene Correspondenz, k. 115-115v: Pro memoria w raporcie z 29 XI 1721.

${ }^{48}$ BJ, rkps 5269, k. 18-18v, 24-25: Szpilowski stolnik rzeczycki do Kawieckiego, Łukówek 4 XII 1721.

${ }^{49}$ Ibidem, np. k. 18-18v, 24-25: Szpilowski stolnik rzeczycki do Kawieckiego, Łukówek 4 XII 1721, s. 142-143: list do Kawieckiego, Luboml 20 III 1722.

${ }^{50}$ Ibidem, s. 103, 115-116: list do Seweryna, Luboml 30 stycznia i 21 II 1722.

${ }^{51}$ BJ, rkps 5269, k. 113-113v: list do J. Szembeka kanclerza wielkiego kor., Łukówek 8 I 1723. 
prawnika. Kawiecki miał wątpliwości, jak Seweryn pogodzi wspomniane zajęcia $\mathrm{z}$ wolą ojca, aby studiował prawo, które wymagało dużo pilności, pracy i czasu. On jednak nie chciał porzucić wybranych zajęć, więc na naukę prawa wyznaczył sobie godzinę ósmą wieczorem, a potrzebował jeszcze czasu na powtarzanie materiału i samodzielną naukę. Ponadto zamierzał uczyć się architektury cywilnej, do czego potrzebował innego nauczyciela niż do architektury wojskowej, oraz muzyki, chociaż jeszcze nie wybrał instrumentu ${ }^{52}$.

Hetman zaplanował dla syna całą podróż edukacyjną, ale plany te ulegały znacznej modyfikacji. Uważał, że powinien mu wystarczyć roczny pobyt $\mathrm{w}$ akademii, do stycznia 1722 r. ${ }^{53}$ Jednak Kawiecki, obawiając się braku pieniędzy, zdecydował o zakończeniu nauki 20 listopada 1721 po trzecim kwartale ${ }^{54}$. Potem Seweryn miał zostać w Paryżu do wiosny, a następnie wyruszyć do Rzymu, by spędzić tam pół roku i wracać do Polski ${ }^{55}$.

Guwerner otrzymał polecenie, aby przed opuszczeniem akademii wcześniej wynajął stancję, ale nie nazbyt wspaniałą, a raczej taką, którą uzna on za mniej kosztowną i najbardziej godną. Obawy hetmana nasiliły się, kiedy Seweryn przeniósł się już z ,akademicznej klazury do wolnej stancji”. Wówczas nakazał Kawieckiemu towarzyszyć synowi podczas wypraw poza stancję. Miał on wszędzie być przy nim obecny i nie pozwalać na samodzielne wychodzenie do miasta i na biesiady, aby strzec go od towarzystwa ,podłych i młodych ludzi”"56. Obawiał się bowiem, aby syn nie zrobił jeszcze gorszego błędu niż w Brukseli57.

Polecał Sewerynowi odwiedzać znaczących ludzi w Paryżu. Powinien złożyć wizytę kardynałowi Polignac oraz posłowi carskiemu Dołgorukiemu. Stale nakazywał Kawieckiemu, aby wszędzie, gdzie przyjadą, prowadził syna „do najpierwszych i najznaczniejszych Jegomości”, aby ten jak najwięcej skorzystał z kontaktów z nimi ${ }^{58}$.

Pomimo zapewnień Kawieckiego, że Seweryn przykłada się do zajęć, hetman nie bardzo wierzył w pilność syna ${ }^{59}$. Narzekał, że chodził on raczej po kabaretach niż przykładał się do nauki i nie słuchał rad guwernera. Martwił się, że Sewerynowi podoba się bardziej czytanie romansów niż „godnych autorów”. Ciągle polecał guwernerowi, aby dbał o jego konwersację, zapoznawał z nowymi ludźmi. Oprócz pilnowania syna guwerner miał też zabraniać mu zbytniej aktywności fizycznej, gdyż Seweryn był skłonny do chorób. Hetman obawiał się zwłaszcza

${ }^{52}$ LNBU, rkps 1311 I, k. 176: list Kawieckiego z Paryża z 17 III 1721.

${ }^{53}$ BJ, rkps 5269, k. 41v-42: hetman do Kawieckiego, Luboml 16 I 1722.

${ }^{54}$ LNBU, rkps 1311 I, k. 178: Kawiecki do hetmana, Paryż 14 XI 1721.

${ }^{55}$ Ibidem, k. 12v-13: hetman do Kawieckiego do Paryża, Łukówek 7 XI 1722.

${ }^{56}$ Ibidem, k. 18-18v: hetman do Kawieckiego, Łukówek, 21 XI 1721.

${ }^{57}$ Ibidem, k. 32-33v: hetman do Kawieckiego, Luboml, 18 XII 1721.

${ }^{58}$ Ibidem, k. 18-18v: hetman do Kawieckiego, Łukówek, 21 XI 1721; k. 32-33v hetman do Kawieckiego, Luboml, 18 XII 1721.

${ }^{59}$ Ibidem, k. 12v-13: hetman do Kawieckiego do Paryża, Łukówek 7 XI 1721. 
sytuacji, gdyby syn, będąc w towarzystwie, za bardzo sobie pofolgował. Przebywając za granicą, powinien być bardziej ostrożny ${ }^{60}$. Za radą Besenvala nakazywał skrócić czas pobytu w Paryżu po zakończeniu nauki w akademii, „by zbyt długo nie bawił się wolnością w świecie" ${ }^{" 61}$.

Hetman stale polecał Kawieckiemu, aby hamował zapędy Seweryna, który kupował wszystko, co mu się podobało. Podkreślał, że mody zmieniają się, a przewóz ubiorów do Polski sporo kosztuje. Polecał przekazać mu, żeby zdobił się w „,noty i piękne talenta”, gdyż one przewyższają zewnętrzne ozdoby ${ }^{62}$. Przypomniał synowi, że szkodę, jaką spowodował w Brukseli, powinien naprawić oszczędnością. Strofował syna, że zamiast tego kupuje stroje, chodzi na kolacje i zmusza Kawieckiego do nowych wydatków. Narzekał, że Seweryn woli bardziej postępować według swej woli niż być posłusznym ojcu. Napominał go, że pojechał po to, aby starać się bardziej rozwijać umysł, niż stroić oraz paść brzuch. Podkreślał, że suknie się zbrudzą i zedrą, oczy napatrzą się towarzystwa, a powinien dbać bardziej o to, co „duszę szlachci i zdobi” i pozostaje aż do śmierci. Chciał, aby syn bardziej liczył się z uczuciami i wolą ojca ${ }^{63}$.

W jednym z ciekawszych listów znajdujemy charakterystyczne przestrogi ojca. Wypominając synowi, że ma już więcej „galonowanych” sukien niż potrzeba, przypominał mu, że nie pojechał za granicę, aby zaprezentować swoją wspaniałą postać. Ma zdobyć wiedzę i nabyć umiejętności, a nie stroić się w modne ubiory, gdyż nie strój i modny i bogaty ubiór zapewnia powagę u ludzi, „ale nauk umiejętność i stateczność chwalebna”. Lepiej mieć wiedzę, mądrość i przezorność niż pieniądze, które podlegają przypadkom losu. Pisał obrazowo: „Nie będziesz ani cła, ani myta od nabytych płacił nauk”. Podkreślał, że syn może wykorzystać swe umiejętności w drodze powrotnej w Wiedniu na dworze cesarskim, który jest blisko Rzeczypospolitej i bywa przydatny do różnych sojuszy. Hetman nakazywał mu zawieranie znajomości z ważnymi i poważanymi ludźmi oraz wystrzeganie się towarzystwa osób nieodpowiedzialnych, skłonnych do zabawy. Radził pielęgnować przyjaźnie z poznanymi ludźmi godnymi zaufania i słuchać różnych opinii, aby nie poprzestawać tylko na własnym osądzie. Na koniec przypomniał o konieczności napisania listów do najważniejszych osób w Rzeczypospolitej przed wyjazdem z Paryża ${ }^{64}$.

Hetman nie ufał w pełni swojemu synowi, gdyż znał jego charakter i upór, dlatego wymagał dokładnych informacji i stałych relacji (przynajmniej co tydzień), aby ulżyć „umartwionemu ojcowskiemu sercu” ${ }^{65}$. Na przykład w lutym 1722 r.

${ }^{60}$ Ibidem, k. 18-18v, 24-25: Szpilowski stolnik rzeczycki do Kawieckiego, Łukówek 4 XII 1721.

${ }^{61}$ Ibidem, k. 32-33v: hetman do Kawieckiego, Luboml 18 XII 1721.

${ }^{62}$ Ibidem, k. 12v-13: hetman do Kawieckiego do Paryża, Łukówek 7 XI 1722.

${ }^{63}$ Ibidem, k. 56-58: hetman do syna Seweryna, Luboml 21 II 1722.

${ }^{64}$ Ibidem, k. 48v-49: hetman do syna Seweryna, Luboml 30 I 1722.

${ }^{65}$ Ibidem, k. 41v-42: hetman do Kawieckiego, Luboml 16 I 1722. 
pisał do syna: „Dostałem po długim milczeniu list z 15 XII 1721. Wymawiasz się febrą. Wiem, że miałeś spokojne chwile w nawrotach choroby, więc mogłeś pisać, mógłbyś wymyśleć inną wymówkę". Przypomniał, że sam dokładnie przestrzega zobowiązań i nie odmawia wykonania swych obietnic i tego samego oczekuje od syna $^{66}$. Natomiast Kawieckiemu przypominał, że ,poczta nie kosztuje WM Pana, ponieważ tu za nią płacę, czasu też zda mi się wielkiego nie trzeba do napisania listu raz w tydzień, choćbyś go dla dojścia duplikować chciał i dwiema drogami posyłać" ${ }^{\prime 67}$. Sam pisał raz w tygodniu lub kazał to robić sekretarzowi Gabrielowi P. Szpilowskiemu, stolnikowi rzeczyckiemu. Kiedy listy nie dochodziły, domagał się szybkiego rozwiązania problemu ${ }^{68}$.

Problemy finansowe, które nie opuszczały hetmana przez cały czas pobytu Seweryna za granicą, nasiliły się od końcowego okresu pobytu w Paryżu i były częściowo przyczyną zmiany terminów wyjazdu. Widząc kłopoty finansowe syna, jeszcze jesienią 1721 r. przez J.V. de Besenvala, ambasadora Francji przy królu polskim, wysłał do Paryża „należący synowi memu suplement” ${ }^{69}$. Informacje o braku pieniędzy skłoniły hetmana, by prosić kanclerza Szembeka, o podanie sposobu szybkiego wysłania 1000 talarów bitych do Paryża. Nie chciał przesyłać pieniędzy do Paryża ze względu na wysokie opłaty i wolny obieg pieniądza ${ }^{70}$. Istniała groźba utraty całej sumy, jeśli wysłany weksel przybyłby do Paryża już po wyjeździe Seweryna ${ }^{71}$. Jednocześnie rozmawiał w Warszawie o wekslu na 10000 zł. Zdecydował się skorzystać z usług bankiera Piotra Riokura, ale musiał opłacić wysokie koszty, aby nie obniżać sumy, jaka dotarłaby do Paryża. Tymczasem kanclerz Szembek zgodził się przekazać na ręce Hoyma 1000 talarów, które przesłano przez Saksonię. Hoym miał zachować tę informację o nowych pieniądzach aż do przybycia do Rzymu, gdzie Kawiecki miał otrzymać jeszcze inny weksel przez nuncjusza. Hetman nie chciał, aby syn domagał się ich na niepotrzebne zakupy ${ }^{72}$.

Ostatecznie hetman wysłał dodatkowo weksel na $10000 \mathrm{zł}$, ale groził synowi, że więcej już nie prześle. Nakazywał Sewerynowi, aby liczył się z nimi tak, jakby te pieniądze były jego i zakazywał naciągania Kawieckiego na dalsze wydatki. Przypominał synowi, że sam dotrzymuje raz danego słowa i wymagał tego samego od niego. Wypomniał mu: „Postanowiłem dawać ci do cudzych krajów po trzydzieści tysięcy na rok, a już sześćdziesiąt wydaję choć jeszcze lat półtora nie masz. Nie kosztowała trzeciej części peregrynacya moja, oyca mego". Nawoływał go do

${ }^{66}$ Ibidem, k. 56-58: hetman do syna Seweryna, Luboml 21 II 1722.

${ }^{67}$ Ibidem, k.67v-68: hetman do Kawieckiego, Luboml 13 III 1722.

${ }^{68}$ Ibidem, k. 72v-73: hetman do Kawieckiego, Luboml 20 III 1722.

${ }^{69} \mathrm{BCz}$, rkps 558 IV, s. 377-378: hetman do Kawieckiego, Nowosiółki 17 X 1721.

${ }^{70}$ BJ, rkps 5269, k. 32-33v: hetman do Kawieckiego, Luboml 18 XII 1721.

${ }^{71}$ Ibidem, k. 55-55v: hetman do J Szembeka kanclerza w.kor., Luboml 13 II 1722.

${ }^{72}$ Ibidem, k. 53v-65 i k. 75v-76: hetman do Kawieckiego, Luboml 6 i 27 III 1722. 
umiarkowania i dbania o ojcowiznę, wskazując, że ma jeszcze brata ${ }^{73}$. Jakież było rozczarowanie ojca, gdy dowiedział się od Kawieckiego, że z powodu wydatków nie byli w stanie wyjechać w planowanym terminie ${ }^{74}$. Okazało się jednak, że sytuacja nie była tak tragiczna, tylko informacja o tym przyszła za późno. Hetman był zły, że syn naraził go niepotrzebnie na zbyt wysokie koszty obsługi bankowej i nakazał przeznaczyć sumę, którą wysłał przez Saksonię na pokrycie kosztów pobytu w Rzymie. Przy tym stale upominał go o „dyskretniejsze szafowane” pieniędzmi ${ }^{75}$.

Z Paryża podróżnicy mieli ruszyć do Rzymu, gdzie zamierzali spędzić pół roku, a potem wracać do Polski ${ }^{76}$. Jednak termin wyjazdu stale odsuwał się aż do karnawału. Potem okazało się, że zamierzali wyruszyć w końcu marca ${ }^{77}$. Następnie mieli wyjechać po karnawale i stanąć na „święte tygodnie”, aby na Boże Narodzenie być w Polsce ${ }^{78}$. Kolejne przesunięcie terminu wyjazdu spowodowała nadzieja na udział w ceremonii koronacji króla Francji w Reims. Dopiero po niej mieli udać się do Piemontu, nie wracając do Paryża. Ojciec miał nadzieję, że podczas ceremonii Seweryn pozna znacznych kawalerów ${ }^{79}$. Brak potwierdzenia terminu koronacji spowodował, że hetman, nie chcąc tracić czasu i pieniędzy, nakazał, aby w tydzień po Wielkanocy wyjechali z Paryża do Włoch, tak by po pobycie w Rzymie i w Wiedniu zdążyć do kraju przed Bożym Narodzeniem ${ }^{80}$. Wyjazd w kwietniu nie doszedł do skutku, więc hetman ponaglał ich, aby wyruszyli w połowie maja najbezpieczniejszym traktem, strzegąc się miejsc, gdzie mogła panować zaraza (były podejrzenia o zarazie w okolicach Lyonu). Mieli jechać drogą, którą jechał do Rzymu kardynał de Rohan, i wstąpić do rezydencji króla Obojga Sycylii, sławnej z olśniewającego dworu i gwardii. Powinni tam zabawić tydzień dla poznania ludzi oraz przyjrzenia się akademii ${ }^{81}$, by Seweryn poznał tamtejszych nauczycieli oraz sam zaprezentował to, czego się nauczy ${ }^{82}$.

Hetman stale nalegał, aby Seweryn doskonalił się w ćwiczeniach i naukach, jakie miał w akademii paryskiej i kontynuował je w drodze, jeśli natrafi na inne akademie $^{83}$. Polecał Kawieckiemu: „Owszem którędykolwiek WM Pan z nim

${ }^{73}$ Ibidem, k. 56-58: hetman do syna Seweryna, Luboml 21 II 1722; k. 81v-83: hetman do Kawieckiego, Targowica 8 IV 1722. Pieniądze miał mieć Besenval albo kupiec Charles Joseph Ferras.

${ }^{74}$ Ibidem, k. 49v-51: hetman do syna Seweryna, Luboml 30 I 1722.

${ }_{75}$ BCz, rkps 558 IV, s. 528-530: Rzewuski do J. Szembeka kanclerza kor., Luboml 6 III 1722.

${ }^{76}$ BJ, rkps 5269, k. 12v-13: hetman do Kawieckiego do Paryża, Łukówek 7 XI 1721.

${ }^{77}$ Ibidem, k. 18-18v: hetman do Kawieckiego, Łukówek 21 XI 1721.

${ }_{78}$ Ibidem, k. 49v-51: hetman do Kawieckiego, Luboml 30 I 1722.

${ }^{79} \mathrm{BCz}$, rkps 558 IV, s. 528-530: hetman do syna Seweryna Luboml, 6 III 1722 oraz BJ, rkps 5269, k. 64.

${ }^{80}$ Ibidem, k. 58-59v: hetman do syna Seweryna, Luboml 6 III 1722.

${ }^{81}$ Ibidem, k. 81v-83: hetman do Kawieckiego, Targowica, 8 IV 1722. Chodzi chyba o Armanda Gastona Maximiliena de Rohan, księcia de Rohan (1674-1749), który był kardynałem od 1712 r.

${ }^{82}$ Ibidem, k. 64: hetman do syna Seweryna, Luboml 6 III 1722.

${ }^{83}$ Ibidem, k. 32-33v: hetman do Kawieckiego, Luboml 18 XII 1721, k. 56-58: hetman do syna Seweryna, Luboml 21 II 1722, k. 134-135: ksiądz Damascen pijar kapelan Rzewuskiego hetmana 
pojedziesz, a będzie akademia i zabawić się dwa dni, trzy dni wielce proszę, aby sobie przypomniał paryskie exercitia [ćwiczenia]". Natomiast mieli omijać inne miejsca tylko przyjemne dla oka, zwłaszcza gdyby było podejrzenie o jakimś niebezpieczeństwa. W drodze nie powinni obciążać się niepotrzebnymi drobiazgami, a zwłaszcza nie brać nikogo do orszaku, ani do służby, ani do towarzystwa „na swój, a raczej na mój koszt" ${ }^{\prime 4}$.

Nie mamy wielu informacji o podróży do Włoch ani o pobycie Seweryna w Rzymie. Ojciec narzekał, że nie otrzymał stamtąd żadnych informacji. Dodawał z przekąsem, że z pewnością dostałby już taki diariusz, „gdybyś był nad nim pracował i przysłał" ". Wiemy, że do Rzymu hetman przesłał weksel na 10000 zł, który jednak nie wystarczył z powodu nadmiernych wydatków Seweryna. Poprzez kanclerza Szembeka musiał prosić przyszłego nuncjusza w Polsce o przekazanie Kawieckiemu stu lub dwustu czerwonych złotych, gdy będzie wyjeżdżał z Rzymu, którą to sumę obiecał oddać nuncjuszowi po jego przyjeździe do Warszawy. Z Rzymu Seweryn i guwerner mieli wyjechać do Wiednia w końcu października ${ }^{86}$. Wiemy, że w listopadzie 1722 r. byli już w Bolonii, gdzie Kawiecki podpisywał kontrakt z kompozytorem włoskim Giovannim A. Ricierim ${ }^{87}$. W czasie podróży hetman zlecał bowiem Kawieckiemu wyszukiwanie różnych osób, np. muzyków czy kuchmistrza, który mógłby „przewyższyć wszystkich tych, których ma Polska z Paryża" ${ }^{\prime 8}$. Następnie w początku grudnia 1722 r. byli w Wenecji ${ }^{89}$.

W tym czasie hetman przygotowywał pobyt syna w Wiedniu. Uważał, że powinien on dłużej zabawić na dworze wiedeńskim, gdyż z racji bliskości i znaczenia politycznego dla Rzeczypospolitej jest on ,do powzięcia znajomości najprzedniejszym". O długości pobytu miał zdecydować guwerner. Ojciec ostrzegał Seweryna, że na dworze wiedeńskim jest wielu pysznych ludzi, którzy mogą doprowadzić go do konfliktów, co byłoby bardzo niebezpieczne"

Przygotowania objęły także finansową stronę pobytu. Już w końcu 1722 r. hetman planował przesłanie dodatkowo 100 czerwonych złotych do Wiednia. W styczniu 1723 r. informował syna, że da mu jeszcze pięć-sześć tysięcy, chociaż

polnego kor. do Seweryna Rzewuskiego starosty chełmskiego, Luboml 13 III 1722, k. 81v-83: hetman do Kawieckiego, Targowica 8 IV 1722.

${ }^{84}$ Ibidem, k. 64: hetman do syna Seweryna, Luboml 6 III 1722.

${ }^{85}$ Ibidem, k. 114-114v: hetman do syna Seweryna, Łukówek 8 I 1723.

${ }^{86}$ Ibidem, k. 108: S.M. Rzewuski do J. Szembeka kanclerza wielkiego kor., Chełm 21 IX 1722.

${ }^{87}$ M. P erz, Ricieri (Riccieri, Riczeri, Rizieri, Rizzeri) Givanni Antonio (1697-1746) kompozytor włoski, w: PSB, t. 31, s. 285-286.

${ }^{88}$ Ibidem, k. 32-33v: hetman do Kawieckiego, Luboml 18 XII 1721; k. 18-18v, 24-25: Szpilowski stolnik rzeczycki do Kawieckiego, Łukówek 4 XII 1721 Temu „kuchmistrzowi a raczej kucharzowi byle przedniemu dam i 100 czerw zł, ale wiatyk 100 talarów to bardzo drogo".

${ }^{89}$ Ibidem, k. 116-116v: hetman do syna Seweryna, Luboml 13 I 1723.

${ }^{90}$ Ibidem, k. 114-114v: hetman do syna Seweryna, Łukówek 8 I 1723. 
wydał już kilkanaście tysięcy ponad umowę zawartą z Kawieckim ${ }^{91}$. Ostatecznie przesłał dodatkowo $8000 \mathrm{zł}$ polskich. Miały one wystarczyć na pobyt i powrót do domu. Ponadto nakazał wydać 2000 zł na piękne karety lub półkarety, „które by i na największą publikę zażywać można"92. W sumie koszty ponad dwuletniego wyjazdu za granicę wynosiły około 80 tysięcy złotych. Hetman pisał do syna, że zdecydował się na dodatkowe wydatki, gdy miał jeszcze niewielką nadzieję, że ta podróż nie zawiedzie jego oczekiwań. Obawiał się jednak, że spełni się zdanie pewnego polityka, iż po długiej chorobie albo długiej podróży mało kto staje się zdrowszy i lepszy. Nakazywał Sewerynowi powrót do kraju po zakończeniu karnawału ${ }^{93}$.

W ten sposób dobiegła końca dość burzliwa podróż edukacyjna Seweryna, która przebiegała pod znakiem dążenia ojca do stworzenia synowi solidnych podstaw do dalszej działalności politycznej w Rzeczypospolitej i utrzymania znaczenia rodziny. Hetman, znając swego syna, obawiał się jej rezultatów, ale nie szczędził własnego czasu i kosztów, aby zakończyła się ona sukcesem. Nie spodziewał się jednak, że syn przysporzy mu tyle kłopotów.

Stanisław M. Rzewuski był kontynuatorem działań swego ojca Michała Floriana, podskarbiego nadwornego koronnego, który budował znaczenie rodu w Rzeczypospolitej. Dążył do tego, aby podróże zagraniczne dobrze przygotowały synów do aktywnego uczestnictwa w życiu politycznym Rzeczypospolitej i ugruntowania pozycji rodu. Widać to także w programie podróży edukacyjnej młodszego syna Wacława, która przebiegała spokojniej, a jej koszty wydają się być zbliżone. Hetman pozostawiał większą swobodę Kawieckiemu, który nadal miał jego zaufanie, i Wacławowi. Wyjechali prawdopodobnie około połowy 1724 r., a do kraju mieli powrócić na zapusty w 1727 r. ${ }^{94}$ Wacław podróżował po Austrii i Francji, aby uzupełnić edukację w Anglii i Holandii, a zakończyć ją na Włoszech i Wiedniu ${ }^{95}$. Hetman oczekiwał, że syn będzie się uczył wszystkiego, co może mu być przydatne w dalszym życiu. Szczególnie rekomendował naukę prawa, które jest najbardziej potrzebne dla utrzymania pozycji rodu podczas starań o różne urzędy. Nalegał, aby zapoznał się z filozofią obecnego wieku, zwłaszcza z filozofią kartezjańską, architekturą wojskową i cywilną ${ }^{96}$. Jednocześnie radził synowi, aby zdobyta nowa wiedza nie przesłaniała tej dawniejszej, jak np. filozofii Arystotelesa, etyki albo nauki rysowania, optyki oraz początków „kawaleryjskiej

91 Ibidem.

92 Ibidem, k. 116-116v: hetman do syna Seweryna, Luboml 13 I 1723; ibidem, k. 120-121: hetman do Kawieckiego jw., Luboml 6 II 1723; jest mowa o 500 czerwonych zł i 2000 na karety.

93 BCz, rkps 558 IV, s. 668-669: hetman do syna Seweryna, [b.d., b.m.] 1723.

94 Ibidem, s. 187-189: hetman do syna Wacława, Olesko, 16 IX 1725.

95 Z. Zi elińs ka, Rzewuski Wacław (dalsze imiona: Piotr, Rafał, Onufry, Ignacy i z bierzmowania Józef) h. Krzywda (1706-1779), hetman polny, a następnie hetman w. kor., kasztelan krakowski wielki koronny, wojewoda betski, w: PSB, t. 34, 1992, s. 169-180.

96 Ibidem, s. 69-71: hetman do syna Wacława, Luboml, 23 II 1725. 
zabawy”, których uczył się jeszcze w Lublinie. Polecał ponadto, aby nauczył się dobrze tańczyć, „gdyż tu każdego stamtąd powracającego kawalera stąd zaraz w najpierwszej probują i cenzurują kompanij”. Uważał, że przyniesie to synowi więcej korzyści niż nauka gry na flecie ${ }^{97}$.

Pomimo różnych zastrzeżeń ojca, po uwzględnieniu dalszych losów jego synów, można uznać, że ten cel został osiągnięty. Nowe pokolenia Rzewuskich kontynuowały tradycję wyjazdów edukacyjnych, aby utrzymać swoją pozycję ${ }^{98}$. Na przykład Wacław, wzorem ojca, organizował podobne podróże swoich dzieci i przygotowywał instrukcje rodzicielskie dla syna i $\operatorname{córek}^{99}$.

\section{HENRYK PALKIJ}

CONCERNS OF THE FATHER SENDING HIS SONS ABROAD FOR EDUCATION IN THE LIGHT OF THE CORRESPONDENCE OF STANISŁAW M. RZEWUSKI, VOIVODE OF PODLASIE IN THE YEARS 1720-1727

Keywords: educational journey, tutor, Seweryn Rzewuski, Stanisław Mateusz Rzewuski, Marcin Kawiecki

\section{Summary}

The paper presents educational trips of sons: Seweryn Józef (older) and Wacław (younger) from the viewpoint of their father Stanisław Mateusz Rzewuski - the Voivode of Podlasie, later the Great Crown Hetman. Seweryn's travel through Germany, Belgium, France, Italy and Austria took place under the custody of Marcin Kawiecki in the years 1720-1723. Knowing his son, the hetman was afraid of the results of the trip, but he did not spare his time and costs to ensure its successful accomplishment. However, he did not expect his son to cause so much trouble to him. The incident in Brussels affected the further course of the trip and forced the hetman to keep reminding the son of his expectations. Seweryn's attitude also made the whole trip much more expensive. Less turbulent was Wacław's trip (from circa the middle of 1724 to circa Easter of 1727), which he made on a similar route, also under Kawiecki's custody. The hetman was satisfied with its results, but he

${ }^{97}$ Ibidem, s. 187-189: hetman do syna Wacława, Olesko, 16 IX 1725.

${ }_{98}$ M. Ka mecka, ,Do cudzych krajów”..., s. 80.

${ }_{99} \mathrm{~A}$. Ku chars ki, Instrukcje rodzicielskie Wacława Rzewuskiego dla syna Seweryna oraz córek Teresy i Ludwiki z lat 1754 i 1763/64, w: „Biuletyn Historii Wychowania” 2017 (3), s. 105-118; Ojcowskie synom przestrogi. Instrukcje rodzicielskie (XVI-XVII w.), oprac. D. Żołądź-Strzelczyk i M.E. Kowalczyk, Wrocław 2018; ibidem: od s. 139 Wacław Piotr Rzewuski, Instrukcje zwiazane z edukacja syna Seweryna w Warszawie i za granica (1754 i 1759), oprac. A. Kucharski; od s. 161 Wacław Piotr Rzewuski, Instrukcja dla syna Józefa do cudzych krajów (1755), oprac. A. Kucharski, od s. 207 Wacław Piotr Rzewuski, Dwie instrukcje wychowawcze dla córek (1763), oprac. A. Kucharski; K. Ma k s i m o w i c z, Hetman Seweryn Rzewuski pod sterem swego ojca Wacława w latach 1774-1779, „Ze Skarbca Kultury” 1989, z. 49, s. 149-189. 
was concerned about his son's passion for flute playing that had emerged in the meantime. The educational trips under consideration were an example of a typical educational path of a young nobleman, which comprised home education, school lessons and travelling abroad. Their aim was to prepare sons for active participation in political life and to reinforce the family's position in the Commonwealth.

\section{ХЕНРИК ПАЛЬКИЙ (HENRYK PALKIJ)}

ЗАБОТЫ ОТЦА, ОТПРАВЛЯЮЩЕГО СЫНОВЕЙ НА ОБУЧЕНИЕ ЗА ГРАНИЦУ

В АСПЕКТЕ ПЕРЕПИСКИ СТАНИСЛАВА М. РЖЕВУСКОГО, ПОДЛЯШСКОГО ВОЕВОДЫ В 1720-1727 ГОДЫ

Ключевые слова: образовательное путешествие, гувернёр, Северин Жевуский, Станислав Матеуш Жевуский, Марцин Кавецкий

\section{Резюме}

Статья представляет поездки, связанные с получением образования, сыновей Северина Юзефа (старшего) и Вацлава (младшего) с точки зрения отца Станислава Матеуша Ржевуского, Подляшского воеводы, позднее Великого гетмана коронного. Путешествие Северина через Германию, Бельгию, Францию, Италию, Австрию проходило под опекой Марцина Кавецкого, и длилось на протяжении 1720-1723 годов. Гетман, зная своего сына, опасался результатов этого путешествия, но и не щадил своего времени и расходов на то, чтобы оно успешно завершилось. Однако Ржевуский не ожидал, что сын доставит ему столько хлопот. Инцидент в Брюсселе повлиял на дальнейший его ход и заставил гетмана постоянно напоминать сыну о своих ожиданиях в отношении его. Поведение Северина также способствовало тому, что значительно увеличились расходы, связанные с этим путешествием. Более спокойно проходило путешествие Вацлава (примерно с половины 1724 года до Пасхи 1727 г.), которое он совершил по похожему маршруту, также под покровительством Кавецкого. Гетман был доволен его ходом, но беспокоился из-за проявившегося большого интереса сына к игре на флейте. Описанные путешествия, связанные с получением образования, были примером типичного пути образования молодого дворянина, которое состояло из домашнего обучения, обучения в школе, заграничных вояжей. Их целью была подготовка сыновей к активному участию в политической жизни и упрочению позиции рода в Речи Посполитой. 